\title{
Characterization of ZnO Thin Films Grown by SILAR Method
}

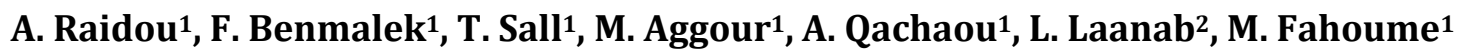 \\ ${ }^{1}$ L.P.M.C., Faculty of Science, Ibn Tofail University, Kénitra, Morocco \\ ${ }^{2}$ L.C.S., Faculty of Science, Mohammed V University, Rabat, Morocco \\ Email: a.raidou@yahoo.fr
}

Received 6 April 2014; revised 14 May 2014; accepted 17 June 2014

Copyright (C) 2014 by authors and OALib.

This work is licensed under the Creative Commons Attribution International License (CC BY). http://creativecommons.org/licenses/by/4.0/

(c) (i) Open Access

\begin{abstract}
Zinc oxide (ZnO) thin films have been deposited using a SILAR (Successive Ionic Layer Adsorption and Reaction) technique, which is based on the alternate dipping of substrate in the solution and distilled water. The thin films were grown on copper, silicon and glass substrates. The precursors for $\mathrm{ZnO}$ films were diluted aqueous solution $\mathrm{ZnSO}_{4}$ complexed with $\mathrm{NH}_{3}$. The films were investigated by X-ray diffraction, scanning electron microscopy, XPS spectroscopy and spectrophotometer. XRD measurement showed that the films were crystallized in the wurtzite phase type with preferred orientation (002). X-ray photoelectron spectroscopy (XPS) was used to monitor changes in oxidation state of $\mathrm{ZnO}$ thin films. The XPS peaks of the $\mathrm{O}_{1 \mathrm{~s}}, \mathrm{Zn}_{2 \mathrm{p} 3 / 2}$ and $\mathrm{Zn}_{2 \mathrm{p} 1 / 2}$ were used for studding the ZnO film. The results of influence of different parameters of SILAR method on phase structure, surface morphology, and optical properties are studied and discussed.
\end{abstract}

\section{Keywords}

ZnO, Substrates Effect, Thin Films, Optical Properties

Subject Areas: Condensed State Physics, Material Experiment, Physical Chemistry

\section{Introduction}

Zinc oxide $(\mathrm{ZnO})$ has been successfully included in the transparent conducting oxides used in modern solid state technology (e.g. Solar cells, optoelectronic devices, sensors, and heat reflecting mirrors). In the last years, a large variety of methods have been employed for the preparation of transparent and conducting ZnO thin films such as, chemical vapor deposition (CVD) [1]-[3], RF magnetron sputtering [4] [5], pulsed laser deposition [6]-[9], photo-atomic layer deposition [10], spray pyrolysis [11] [12], metal oxide chemical vapor deposition (MOCVD) [13], electrodeposition [14], sol-gel process [15] [16], chemical bath deposition (CBD) [17] and successive ionic layer adsorption and reaction (SILAR) [18], etc. In the chemical bath deposition technique, the

How to cite this paper: Raidou, A., Benmalek, F., Sall, T., Aggour, M., Qachaou, A., Laanab, L. and Fahoume, M. (2014) Characterization of ZnO Thin Films Grown by SILAR Method. Open Access Library Journal, 1: e588.

http://dx.doi.org/10.4236/oalib.1100588 
formation of films takes place when ionic product exceeds solubility product (IP > SP). This result in a formation of precipitation in the solution and the control over the process is lost [19]. In order to overcome this problem, the $\mathrm{ZnO}$ thin film is prepared by SILAR technique which is economical, highly feasible for large area deposition and wastage of chemicals can be avoided.

There are several factors that influence the properties of $\mathrm{ZnO}$ thin films such the thermal annealing [20] [21] and the nature of substrate [22].

\section{Experiment}

The SILAR method is mainly based on the adsorption and reaction of the ions from the solution and rinsing between every immersion with deionised water to avoid homogeneous precipitation in the solution.

In general, the SILAR growth cycle contains four different steps: adsorption, rinsing, reaction and rinsing. Rinsing follows each reaction, which enables heterogeneous reaction between the solid phase and the solvated ions in the solution.

The deposition of $\mathrm{ZnO}$ thin films on copper, silicon and glass slides $(75 \mathrm{~mm} \times 25 \mathrm{~mm} \times 1 \mathrm{~mm}$ ) substrates was achieved using zinc sulphate and $6 \mathrm{ml} / 100 \mathrm{ml} 13.15 \mathrm{M}$ aqueous ammonia solution as precursor solution. The $\mathrm{pH}$ was adjusted by addition of a small amount of $\mathrm{KOH}$. Using the same method, Jimenez-Gonzalez and co-workers [18] [23] have prepared the $\mathrm{ZnO}$ films and studied their photosensitivity. In the first step, the substrate was immersed in a beaker containing $\mathrm{Zn}\left(\mathrm{SO}_{4}\right)$ and ammonia solution, where $\mathrm{Zn}^{2+}$ with ammonia formed zinc ammonia complex $\left(\left[\mathrm{Zn}\left(\mathrm{NH}_{3}\right)_{4}\right]^{2+}\right)$. In the first immersion process, zinc ammonia was adsorbed onto the substrate. In the second step, the zinc ammonia adsorbed substrate was immersed into beaker containing the distilled water, where the adsorbed zinc ammonia complex was converted into zinc hydroxide $\left(\mathrm{Zn}(\mathrm{OH})_{2}\right)$. Each immersion step took a time period of $30 \mathrm{~s}$. the detailed chemical reactions involved in the SILAR growth process are given as follows

$$
\begin{aligned}
& {\left[\mathrm{Zn}\left(\mathrm{NH}_{3}\right)_{4}\right]^{2+}+4 \mathrm{H}_{2} \mathrm{O} \rightarrow \mathrm{Zn}^{2+}+4 \mathrm{NH}_{4}^{+}+4 \mathrm{OH}^{-}} \\
& \mathrm{Zn}^{2+}+2 \mathrm{OH}^{-} \rightarrow \mathrm{Zn}(\mathrm{OH})_{2}
\end{aligned}
$$

In order to consider the transformation of the hydroxide phase during the heat treatment, $\mathrm{Zn}(\mathrm{OH})_{2}$ could be written in a equivalent form, in the Kofstadt notation [24] [25]

$$
\mathrm{Zn}(\mathrm{OH})_{2} \leftrightarrow\left[\mathrm{Zn}^{2+}+2\left(\mathrm{O}^{2-}+\mathrm{H}^{+}\right)\right]^{\text {(solid) }}
$$

At higher temperature in air atmosphere, the hydroxide phase (Equation (3)) is transformed into oxide phase,

$$
\begin{aligned}
& {\left[\mathrm{Zn}^{2+}+2\left(\mathrm{O}^{2-}+\mathrm{H}^{+}\right)\right]^{\text {(solid) }}+\mathrm{O}_{2}^{\text {gas }} \stackrel{T}{\longleftrightarrow}\left[\mathrm{Zn}^{2+}+\mathrm{O}^{2-}\right]^{\text {(solid) }}+\left(\mathrm{O}^{2-}+2 \mathrm{H}^{+}\right)^{\text {(gas) }}+\mathrm{O}_{2}^{\text {(gas) }}} \\
& =[\mathrm{ZnO}]^{\text {(solid) }}+\mathrm{H}_{2} \mathrm{O}+\mathrm{O}_{2}^{\text {(gas) }}
\end{aligned}
$$

The crystal structure was determined with a XPERT-PRO PW-3064 X-ray diffractometer using $\mathrm{Cu} K \alpha(\lambda=$ 1.540598 Á). The optical characterization of the films was done by Perkin Elmert Instrument lambda 900 UV/Vis/NIR spectrophotometer.

\section{Structural Studies}

Figure 1 shows two XRD patterns of $\mathrm{ZnO}$ particles synthesized on copper and glass substrates at bath temperature $80^{\circ} \mathrm{C}, \mathrm{pH} 10.5$, cycles number 20 , immersion time $30 \mathrm{~s}, 0.04 \mathrm{M}$ of $\mathrm{ZnSO}_{4}$ and annealed at $450^{\circ} \mathrm{C}$ for 2 hours. All the peaks of $\mathrm{ZnO}$ indicate that the particles are hexagonal wurtzite structure $\mathrm{ZnO}$, and the diffraction data are in good agreement with ASTM card [PDF No. 79-207, a = 3.2648 $\AA$ and $\mathrm{c}=5.2194 \AA$ ] . The exploitation of the spectrum of Figure 1(a) reveals that the film is polycrystalline. In addition to the peaks relating to the copper substrate, the X-ray diffraction spectrum shows four peaks due to the diffraction of (100), (002), (101) and (102) planes. And there are also the peaks of the copper oxide which are due to contamination of the copper substrate during annealing. For Figure 1(b) No peaks for other impurities like metallic zinc were detected in the spectrum. It indicates that the product obtained is purely composed from $\mathrm{ZnO}$. The indexed $\mathrm{ZnO}$ peaks in the spectrum 

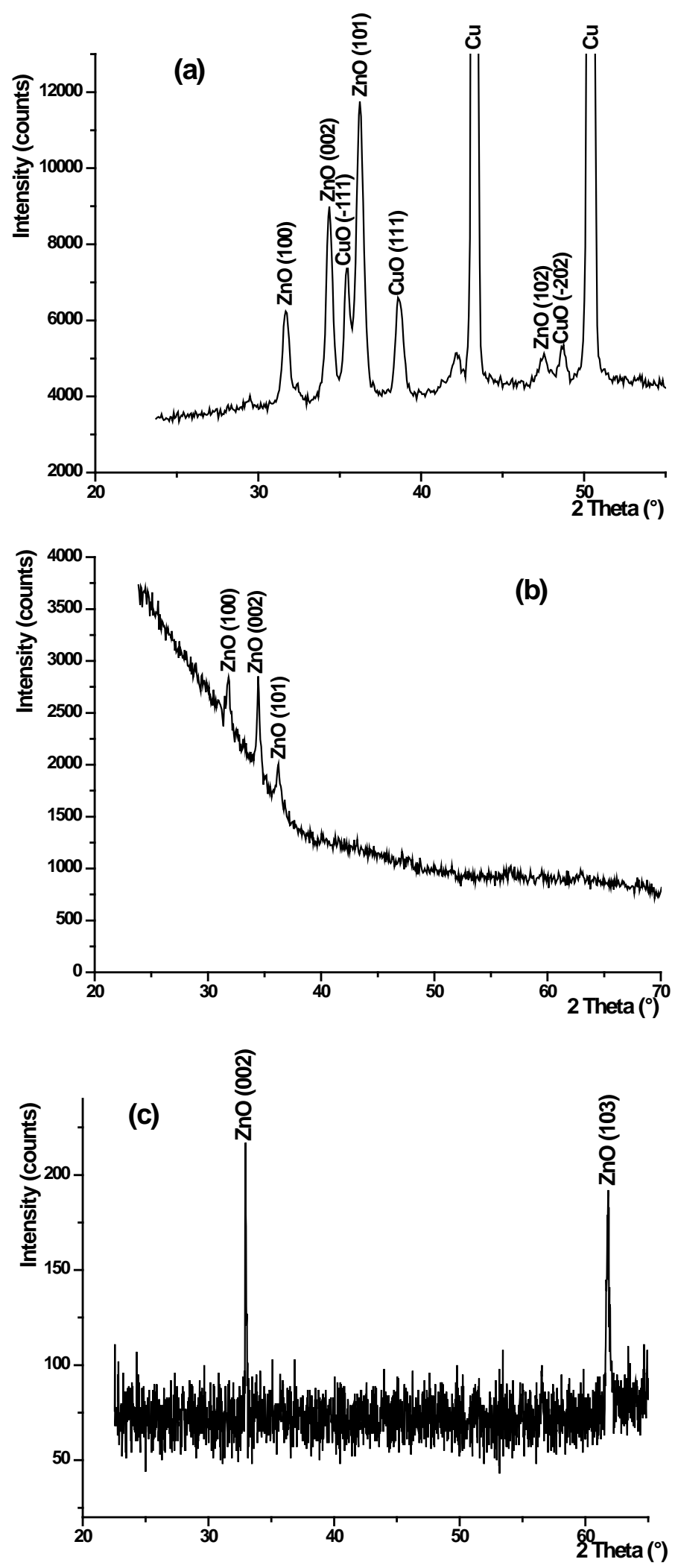

Figure 1. The X-ray diffraction patterns of the $\mathrm{ZnO}$ films deposited onto the, (a) copper, (b) glass, and (c) silicon substrates at bath temperature $80^{\circ} \mathrm{C}, \mathrm{pH} 10.5$, cycles number 20 , immersion time $30 \mathrm{~s}$. 
have preferred orientation (002), and the sharp and narrow spectral width, which indicates excellent crystal quality of the product. Figure 1(c) reveals the presence of only two diffraction peaks (002) and (103). The intensities of theses peaks are very low showing that the $\mathrm{ZnO}$ films are nanocrystalline structure.

\section{Morphological Studies}

Figure 2 shows the SEM images of ZnO thin films grown on different substrates ((a) copper, (b) silicon and (c) glass). As can be seen, the morphology of the obtained $\mathrm{ZnO}$ structures strongly depends on the substrate. And it is observed that our films are relatively not dense.

From Figure 2(a) it can be seen that the film is consisted by rods with an average size of $750 \mathrm{~nm}$ were obtained by using the $\mathrm{Cu}$ substrate. And we note that we found other shapes of grains of $\mathrm{ZnO}$ thin films deposited on the same substrate as the needles, and the hexagonal form that their size of the grains increases with the annealing temperature. From Figure 2(b), it is clearly observed that the grains forming the $\mathrm{ZnO}$ thin film deposited on Si substrate take the shape of small flowers, and also one obtained the shape of spindle for the grains of $\mathrm{ZnO}$ deposited on the Si substrate. The Figure 2(c) reveals the grains of $\mathrm{ZnO}$ thin film take the shapes of the nanoprisms and the flowers.

We note that all the particles of our samples result from the lengthened nanocrystal association.

\section{Optical Properties}

Figure 3(a) shows the transmittance spectra of $\mathrm{ZnO}$ films coated on glass. These films had a good transmission (72\% - 90\%) in VIS and NIR domains (300 nm - $1100 \mathrm{~nm}$ ). It is observed that the transmittance increases with the increase in the $\mathrm{pH}$.

Figure 3(b) presents the optical absorbance spectra of the samples deposited at $\mathrm{pH} 10.5$ and $\mathrm{pH}$ 12.1. These spectra reveal that the $\mathrm{ZnO}$ thin films have low absorbance in the visible region, which is a characteristic of $\mathrm{ZnO}$. Also these figures show the occurrence of peaks in the absorbance (transmittance) plot. These peaks are attributed to the formation of excitons in ZnO. Similar peaks were obtained by other authors [26] [27] after annealing of $\mathrm{ZnO}$ thin films.

Figure 3(c) exhibit the reflectance spectra, which indicate when the $\mathrm{pH}$ is increased the reflectance decreases. The reflectance spectra decrease and tend towards 10 for $\mathrm{pH} 10.5$ and 5 for $\mathrm{pH}$ 12.1.

The energy gap is preferred to be evaluated from the optical absorption. A stoichiometric composition of the films is indicated by a sharp absorption edge at a wavelength that corresponds to the forbidden energy gap. Nearly at the absorption edge, the absorption coefficient can be calculated using the expression [28]

$$
\alpha=\frac{1}{d} \ln \frac{\left(1-R^{2}\right)}{T}
$$

where $d$ denotes the film thickness, $R$ and $T$ are the reflection and transmission coefficients, respectively.

The fundamental absorption may be due either to allow direct transitions described by the well known Tauc's relationship [29].
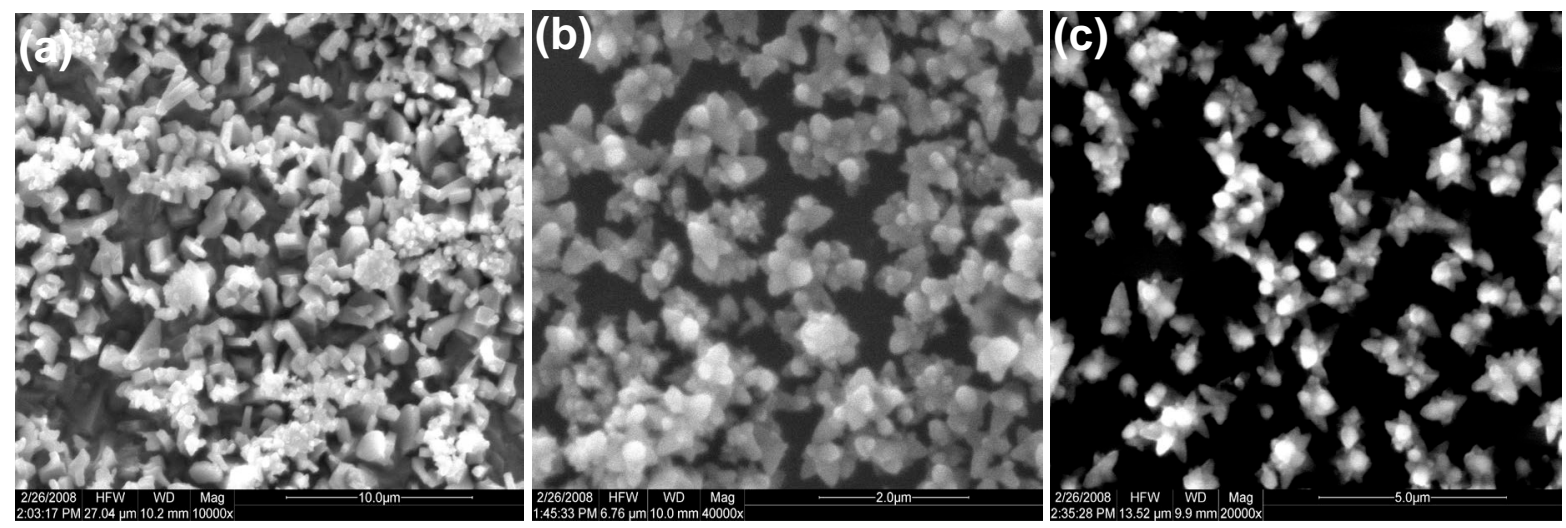

Figure 2. The SEM images of the ZnO films deposited onto different substrates, (a) Copper, (b) Silicon and (c) Glass. 

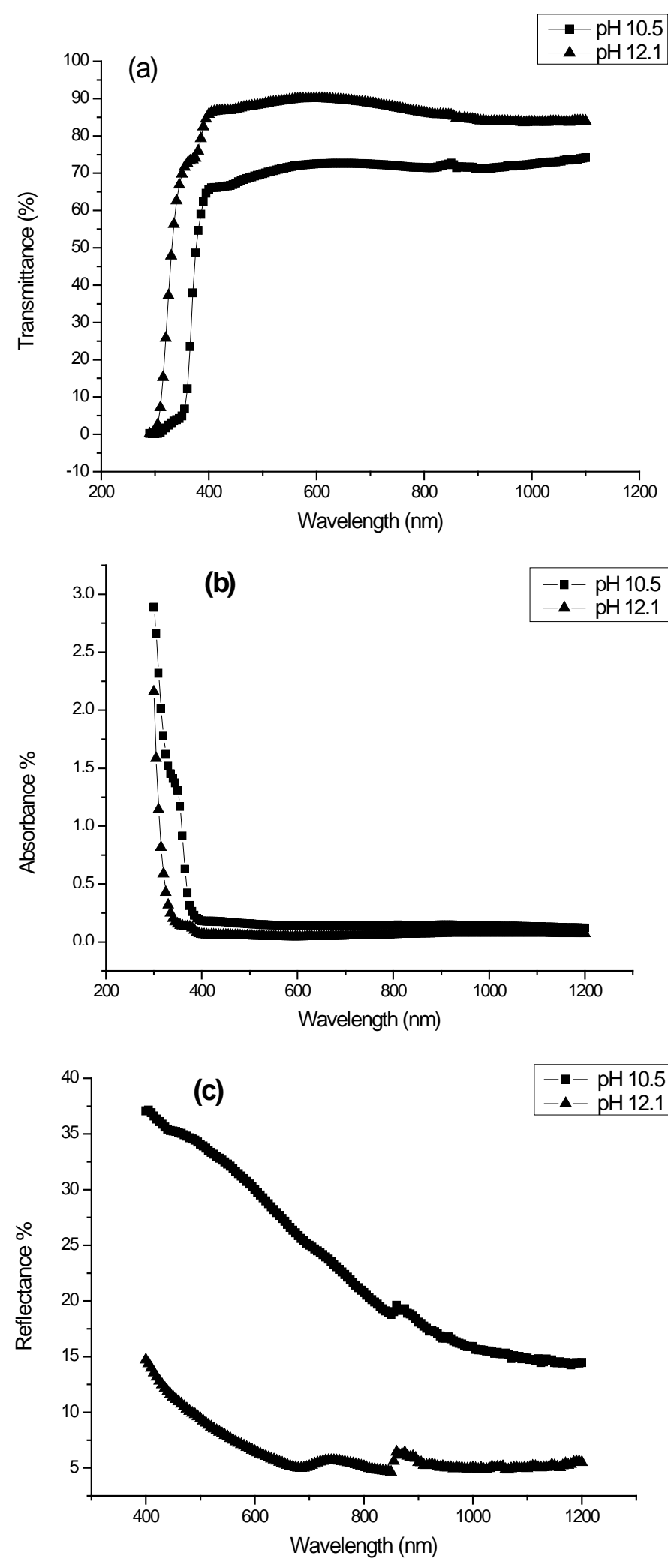

Figure 3. (a) Transmission, (b) Absorbance, and (c) Reflectance spectra for $\mathrm{ZnO}$ thin films deposited on glass substrates, at $\mathrm{pH} 10.5$ and $\mathrm{pH}$ 12.1 . 


$$
\alpha h v=A_{a}\left(h v-E_{g}\right)^{\frac{1}{2}}
$$

Or to forbidden direct transitions described by

$$
\alpha h v=A_{f}\left(h v-E_{g}\right)^{\frac{3}{2}}
$$

where $h v$ is the incident photon energy, $E_{g}$ represents the energy band gap, $A_{a}$ and $A_{f}$ are the characteristic parameters, independent of the photon energy for respective transitions.

According to Equation (5), in the vicinity of fundamental absorption edge the dependence $(\alpha h v)^{2}=f(h v)$ is linear. This means that ZnO films have direct band gap energy, which is in accordance with the energy band models proposed for hexagonal ZnO. This is confirmed by plotting $(\alpha h v)^{2}$ versus $h v$ (Figure 4). The values for the band gap width, $E_{g}$, have been determined by extrapolating the linear portions of the respective curves to $(\alpha h v)^{2}=0$.

For the investigated samples, these values of energy band gap calculated from absorption spectra $3.12 \mathrm{eV}$ for $\mathrm{pH}=12.1$ and $3.32 \mathrm{eV}$ for $\mathrm{pH}=10.5$. The last value is in good agreement with the values for bulk ZnO crystals. But $E_{g}=3.12 \mathrm{eV}$ is smaller, this is due to the change in the grains shape and the decrease in thickness of the thin film.

\section{Chemical Characterization (XPS)}

X-ray photoelectron spectroscopy (XPS) was used to monitor changes in the stoichiometry and oxidation state of $\mathrm{ZnO}$ thin films. The figure show XPS spectra of $\mathrm{O}_{1 \mathrm{~s}}$ and $\mathrm{Zn}_{2 \mathrm{p}}$ core level region of $\mathrm{ZnO}$ films measured after heat treatment, and deposited on copper substrates.

From the Figure 5(b), the two different $\mathrm{O}_{1 \mathrm{~s}}$ states indicated the presence of two different oxygen-bonding states at the surface. The peak with $E_{B}$ near $530 \mathrm{eV}$ confirms that a fraction of the surface is composed of stoichiometrically bonded oxygen of ZnO. A neighbouring peak, near $532 \mathrm{eV}$, was attributed to non-stoichiometric $\mathrm{ZnO}$.

The Figure 5(c) shows XPS peaks at $\sim 1022.47$ and $\sim 1045.82 \mathrm{eV}$. The binding energy difference between $\mathrm{Zn}_{2 \mathrm{p} 3 / 2}$ and $\mathrm{Zn}_{2 \mathrm{p} 1 / 2}$ is $\sim 23 \mathrm{eV}$ which is a characteristic value of $\mathrm{ZnO}$.

\section{Conclusions}

ZnO thin films were synthesized on copper, silicon and glass substrates by SILAR process employing zinc sulphate as source of zinc.

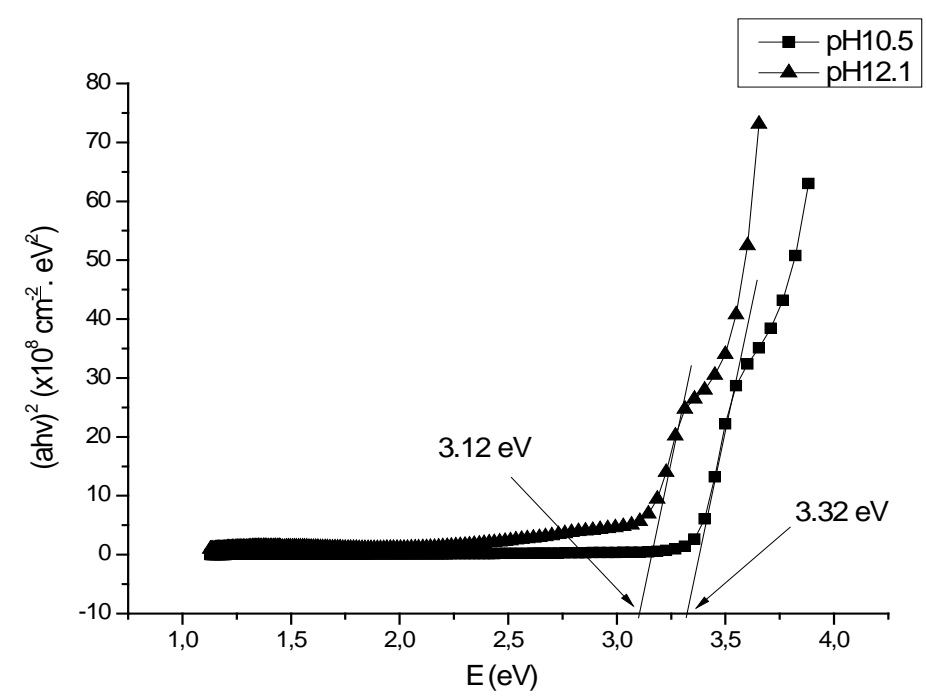

Figure 4. Spectral dependence of the absorption coefficient, $(\alpha h v)^{2}=\mathrm{f}(h v)$, for $\mathrm{ZnO}$ samples deposited on glass substrates at $\mathrm{pH} 10.5$ and $\mathrm{pH} 12.1$. 

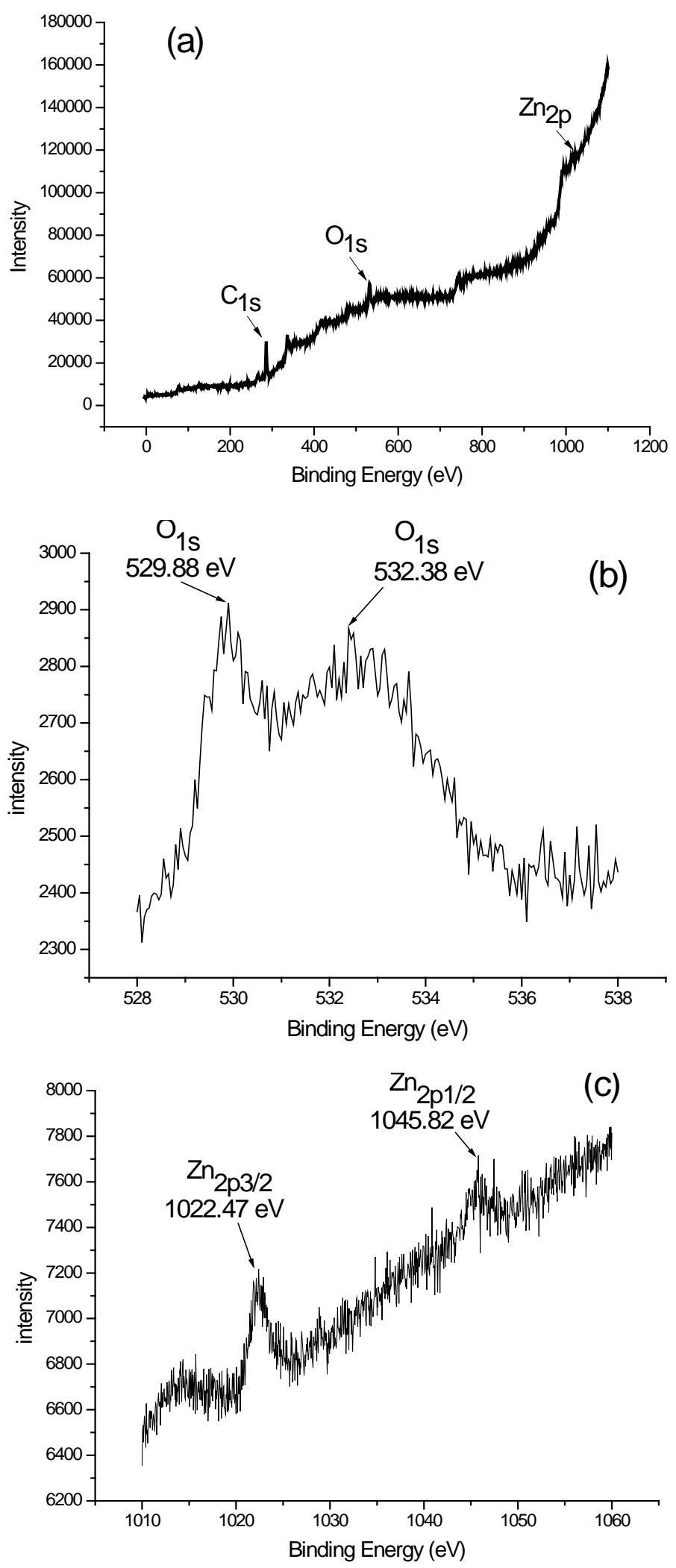

Figure 5. (a) XPS survey spectra of ZnO thin film, (b) and (c) corresponding to the $\mathrm{Zn}_{2 \mathrm{p}}$ and $\mathrm{O}_{1 \mathrm{~s}}$ core levels of $\mathrm{ZnO}$ supported on copper substrate at $80^{\circ} \mathrm{C}$ after annealing in air at $450^{\circ} \mathrm{C}$ for $2 \mathrm{~h}$. 
The crystallites are preferentially oriented with (002) plane parallel to the substrate surface. The SEM micrographs revealed different shapes of $\mathrm{ZnO}$ thin films, which depend of various deposit parameters. Optical properties study exhibit direct band gap nature with band gap energy $3.12 \mathrm{eV}$ and $3.32 \mathrm{eV}$, depending on the $\mathrm{pH}$.

\section{References}

[1] Kasuga, M. and Mochizuki, M. (1981) Orientation Relationships of Zinc Oxide on Sapphire in Heteroepitaxial Chemical Vapor Deposition. Journal of Crystal Growth, 54, 185-194. http://dx.doi.org/10.1016/0022-0248(81)90459-0

[2] Ghandi, S.K., Field, R.J. and Shealy, J.R. (1980) Highly Oriented Zinc Oxide Films Grown by the Oxidation of Diethylzinc. Applied Physics Letters, 37, 449. http://dx.doi.org/10.1063/1.91960

[3] Barnes, T.M., Leaf, J., Fry, C. and Wolden, C.A. (2005) Room Temperature Chemical Vapor Deposition of c-Axis ZnO. Journal of Crystal Growth, 274, 412-417. http://dx.doi.org/10.1016/j.jcrysgro.2004.10.015

[4] Zhou, Y., Kelly, P.J., Postill, A., Zeid, O.A. and Almajjar, A.A. (2004) The Characteristics of Aluminium-Doped Zinc Oxide Films Prepared by Pulsed Magnetron Sputtering from Powder Targets. Thin Solid Films, 447-448, 33-39. http://dx.doi.org/10.1016/j.tsf.2003.09.018

[5] Fu, E.G., Zhang, D.M., Zhang, G., Ming, Z., Yang, Z.F. and Liu, J.J. (2004) Properties of Transparent Conductive ZnO:Al Thin Films Prepared by Magnetron Sputtering. Microelectronics Journal, 35, 383-387. http://dx.doi.org/10.1016/S0026-2692(03)00251-9

[6] Kaidashev, E.M., Lorenz, M., Wenckstern, H.V., Rahm, A., Semmelhack, H.C., Han, K.H., Benndorf, G., Bundesmann, C., Hochmuth, H. and Grundmann, M. (2003) High Electron Mobility of Epitaxial ZnO Thin Films on $c$-Plane Sapphire Grown by Multistep Pulsed-Laser Deposition. Applied Physics Letters, 82, 3901. http://dx.doi.org/10.1063/1.1578694

[7] Cracium, V., Elders, J., Gardeniers, J.G.E. and Boyd, I.W. (1994) Characteristics of High Quality ZnO Thin Films Deposited by Pulsed Laser Deposition. Applied Physics Letters, 65, 2963. http://dx.doi.org/10.1063/1.112478

[8] Srikant, V., Sergo, V. and Clarke, D.R. (1995) Epitaxial Aluminum-Doped Zinc Oxide Thin Films on Sapphire: I, Effect of Substrate Orientation. Journal of the American Ceramic Society, 78, 1931-1934. http://dx.doi.org/10.1111/j.1151-2916.1995.tb08912.x

[9] King, S.L., Gardeniers, J.G.E. and Boyd, I.W. (1996) Pulsed-Laser Deposited ZnO for Device Applications. Applied Surface Science, 96-98, 811-818. http://dx.doi.org/10.1016/0169-4332(96)80027-4

[10] Saito, K., Watanabe, Y., Takahashi, K., Matsuzawa, T., Sang, B. and Konagai, M. (1997) Photo Atomic Layer Deposition of Transparent Conductive ZnO Films. Solar Energy Materials and Solar Cells, 49, 187-193. http://dx.doi.org/10.1016/S0927-0248(97)00194-3

[11] Lee, J.H. and Park, B.O. (2004) Characteristics of Al-Doped ZnO Thin Films Obtained by Ultrasonic Spray Pyrolysis: Effects of Al Doping and an Annealing Treatment. Materials Science and Engineering: B, 106, 242-245. http://dx.doi.org/10.1016/j.mseb.2003.09.040

[12] Ma, T.Y. and Lee, S.C. (2000) Effects of Aluminum Content and Substrate Temperature on the Structural and Electrical Properties of Aluminum-Doped ZnO Films Prepared by Ultrasonic Spray Pyrolysis. Journal of Materials Science: Materials in Electronics, 11, 305-309. http://dx.doi.org/10.1023/A:1008925315123

[13] Pagni, O., Somhlahlo, N.N., Weichsel, C. and Leitch, A.W.R. (2006) Electrical Properties of ZnO Thin Films Grown by MOCVD. Physica B: Condensed Matter, 376-377, 749-751. http://dx.doi.org/10.1016/j.physb.2005.12.187

[14] Fahoume, M., Maghfoul, O., Aggour, M., Hartiti, B., Chraibi, F. and Ennaoui, A. (2006) Growth and Characterization of ZnO Thin Films Prepared by Electrodeposition Technique. Solar Energy Materials and Solar Cells, 90, 1437-1444. http://dx.doi.org/10.1016/j.solmat.2005.10.010

[15] Tang, W. and Cameron, D.C. (1994) Aluminum-Doped Zinc Oxide Transparent Conductors Deposited by the Sol-Gel Process. Thin Solid Films, 238, 83-87. http://dx.doi.org/10.1016/0040-6090(94)90653-X

[16] Natsume, Y. and Sakata, H. (2000) Zinc Oxide Films Prepared by Sol-Gel Spin-Coating. Thin Solid Films, 372, 30-36. http://dx.doi.org/10.1016/S0040-6090(00)01056-7

[17] Ennaqoui, A., Weber, M., Scheer, R. and Lewerenz, H.J. (1992) Chemical-Bath ZnO Buffer Layer for CuInS2 ThinFilm Solar Cells. Solar Energy Materials and Solar Cells, 54, 277-286. http://dx.doi.org/10.1016/S0927-0248(98)00079-8

[18] Jiménez-González, A. snd Suarez-Parra, R. (1996) Effect of Heat Treatment on the Properties of ZnO Thin Films Prepared by Successive Ion Layer Adsorption and Reaction (SILAR). Journal of Crystal Growth, 167, 649-655. http://dx.doi.org/10.1016/0022-0248(96)00308-9

[19] Lokhande, C.D., Sankapal, B.R., Sarate, S.D., Pathan, H.M., Giersig, M. and Ganeshan, V. (2001) A Novel Method for the Deposition of Nanocrystalline Bi2Se3, Sb2Se3 and Bi2Se3-Sb2Se3 Thin Films-SILAR. Applied Surface Science, 
182, 413-417. http://dx.doi.org/10.1016/S0169-4332(01)00461-5

[20] Zhai, J., Zhang, L. and Yao, X. (2000) The Dielectric Properties and Optical Propagation Loss of $c$-Axis Oriented ZnO Thin Films Deposited by Sol-Gel Process. Ceramics International, 26, 883-885. http://dx.doi.org/10.1016/S0272-8842(00)00031-6

[21] Gosh, R., Mallik, B., Fujihara, S. and Basak, D. (2005) Photoluminescence and Photoconductance in Annealed ZnO Thin Films. Chemical Physics Letters, 403, 415-419. http://dx.doi.org/10.1016/j.cplett.2005.01.043

[22] Gosh, R., Basak, D. and Fujihara, S. (2004) Effect of Substrate-Induced Strain on the Structural, Electrical, and Optical Properties of Polycrystalline ZnO Thin Films. Journal of Applied Physics, 96, 2689. http://dx.doi.org/10.1063/1.1769598

[23] Jimenez-Gonzalez, A. and Nair, P.K. (1995) Photosensitive ZnO Thin Films Prepared by the Chemical Deposition Method SILAR. Semiconductor Science and Technology, 10, 1277. http://dx.doi.org/10.1088/0268-1242/10/9/013

[24] Kofstadt, P. (1983) Nonstoichimetry, Diffusion and Electrical Conductivity in Binary Metal Oxides. Krieger, Malabar, Charpter 1, 7.

[25] Kroeger, F.H. and Vink, H. (1956) In: Seitz, F. and Turnbull, D., Eds., Solid State Physics, Academic Press, New York, Vol. 3, Charpter 2, 397.

[26] Ren, F., Jiang, C.Z. and Xiao, X.H. (2007) Nanotechnology, 18, Article ID: 285609.

[27] Gosh, A., Desphande, N.G., Gudage, Y.G., Joshi, R.A., Sagade, A.A., Phase, D.M. and Sharma, R. (2009) Effect of Annealing on Structural and Optical Properties of Zinc Oxide Thin Film Deposited by Successive Ionic Layer Adsorption and Reaction Technique. Journal of Alloys and Compounds, 469, 56-60. http://dx.doi.org/10.1016/j.jallcom.2008.02.061

[28] Hodgson, J.N. (1970) Optical Absorption and Dispersion in Solids. Chapman \& Hall, London.

[29] Tauc, J., Grigorovici, R. and Vancu, A. (1966) Optical Properties and Electronic Structure of Amorphous Germanium. Physica Status Solidi (b), 15, 627-637. http://dx.doi.org/10.1002/pssb.19660150224 